\title{
A difícil e lenta entrada da violência na agenda do setor saúde
}

A violência é, antes de tudo, uma questão social e, portanto, em si, não é objeto próprio do setor saúde. Ela se torna um tema desse campo: (1) pelo impacto que provoca na qualidade de vida; pelas lesões físicas, psíquicas e morais que acarreta e pelas exigências de atenção e cuidados dos serviços médico-hospitalares; também, (2) pela concepção ampliada de saúde, a violência é objeto da intersetorialidade, na qual o campo médico-social se integra.

Embora já ninguém duvide que violências e acidentes sejam problemas que afetam a saúde, ao longo dos anos esses fenômenos vêm sendo tratados como objeto exclusivo da segurança pública. Apenas na década de 90 o setor começou a assumi-los oficialmente. Observando as mudanças nos perfis de mobimortalidade na maioria das regiões latinoamericanas, a Organização Pan-Americana da Saúde, a partir de 1993, passou a recomendar, insistentemente, aos países membros que incluíssem o tema na sua agenda de intervenção. Mais tarde, percebendo a gravidade da situação em muitas outras partes do mundo e não só na região das Américas, a Organização Mundial da Saúde (OMS) dedicou-lhe prioridade na Assembléia Mundial de Saúde em 1997. E em 2002, a OMS publicou extenso informe denominado Relatório Mundial sobre Violência e Saúde, trazendo para a área, uma reflexão sobre sua responsabilidade específica e intersetorial.

No Brasil, também foi difícil introduzir o assunto dos Acidentes e Violências na agenda da política de saúde, apesar de, desde a década de 1980, esses eventos constituírem a segunda causa de óbito no perfil da mortalidade geral. Desde então, essa situação vem sendo evidenciada e publicizada por pesquisadores e estudiosos do conceito e das informações sobre "causas externas", rubrica que na Classificação Internacional de Doenças designa as mortes, as lesões e os traumas derivados do fenômeno. No final da década de 90, mais precisamente em 1998, depois da Assembléia Mundial de 1997 que privilegiou o assunto, o Ministério da Saúde criou um Comitê Técnico com a finalidade de diagnosticar e de propor ações específicas para o setor. Tive o privilégio de ser a Presidente desse Comitê que compartilhou com mais 150 profissionais de todo o país a discussão da proposta, posteriormente analisada e aprovada pelas instâncias tripartites do SUS e pelo Conselho Nacional de Saúde. Em 16 de maio de 2001 (não sem muitos percalços e delongas), o documento foi oficializado por portaria com a seguinte denominação: Política Nacional de Redução da Morbimortalidade por Acidentes e Violências. Esse documento contém a definição dos conceitos, o diagnóstico da situação, as diretrizes e as estratégias de ação intersetorial, ressaltando a responsabilidade do setor.

Hoje estão em curso muitas ações de nível nacional, estadual e municipal de prevenção da violência e dos acidentes, algumas existem antes da portaria que define a política, e outras, inspiradas nela. No momento presente, está sendo elaborado um Plano de Ação que orientará e integrará as diversas perspectivas e iniciativas nacionais. Tudo tem sido muito lento e há vários motivos para isso. O principal é que, numa área dominada pela mentalidade biomédica, "as violências e os acidentes" costumam ser vistos como um objeto estranho a seu universo conceitual. Porém, é preciso que todos saibam que o perfil de mortalidade e da morbidade da população brasileira hoje é marcado mais pelas condições, situações e estilos de vida do que pelas enfermidades tradicionais. Violências e acidentes fazem parte desses problemas que devem merecer tanta atenção como a AIDS, o câncer e as enfermidades cárdio-vasculares. 